The $5^{\text {th }}$ International Conference on Family Business and Entrepreneurship

\title{
WOMEN EMPOWERMENT THROUGH LOKAL WISDOM AS PRODUCTION DIFFERENTIATION STRATEGY
}

\author{
Yeyen Komalasari ${ }^{1^{*}}$, Eka Putri Suryantari ${ }^{2}$, Tjokorda Bagus Putra Marhaendra ${ }^{3}$ \\ ${ }_{1,2,3}$ Faculty of Business, Universitas Dhyana Pura \\ Corresponding author: yeyenkomalasari@ undhirabali.ac.id
}

\begin{abstract}
:
This article explores the application of production differentiation strategy by women empowerment through local wisdom of Nasi Koco in the herritage area, Gajah Mada Street, Denpasar-Bali. The purpose of this article is to increase the sales of Nasi Koco by implementing new strategies to win the competition in similar businesses that have sprung up. The strategy that can be offered is a product differentiation, so that the product is more varied and not monotonous, that attracts consumer interest. The product differentiation strategy offered refers more to women's empowerment through local wisdom, namely making products or food variations needed for ceremonies, where as we know people's lives in Bali are full of a series of religious ceremonies. The study employed qualitative approaches using narrative research by observation, interview, and documentation. The result of the study base on an in-depth interview with Balinese women who understand Balinese traditional culture, the advice that can be given is to make product variations, not just Nasi Jinggo or Nasi Wrap as usual, but to make it more varied. Suggested variations are Nasi Tumpeng, Nasi Yasa, and Nasi Kelangi, which are usually used for traditional activities in Bali.
\end{abstract}

Keywords: Production differentiation strategy, women empowerment, local wisdom, traditional culture, Nasi Koco

\section{Introduction}

Introductory Nasi Koco is a name for rice wrap which is commonly called Nasi Jinggo. To distinguish this Nasi Jinggo from other Nasi Jinggo, it is given a unique name, namely, "Nasi Koco", of course also with a distinctive taste that is different from most Nasi Jinggo. Currently, Nasi Jinggo is one type of culinary that is not only in demand by local people but also by tourists visiting the island of Bali. Small in shape, wrapped in banana leaves, simple side dishes and spicy taste are the hallmarks of Nasi Jinggo. Besides the delicious taste, cheap price and affordable for all people, making Nasi Jinggo is the right choice for lovers. Nasi Koco is a food that can be consumed every day. The beginning of its appearance in Denpasar City in the 1980s was first sold on Jalan Gajah Mada Denpasar, which is now referred to as the herritage area.

Ni Nyoman Puji is a business owner and the initiator of Nasi Koco, a woman who tries to improve the welfare of her family and the surrounding environment by entrepreneurship in the culinary field. She plays a role in increasing the women empowerment in the surrounding environment by inviting her to participate as a distributor of her Nasi Koco business.

This is a community service activity with funding from the Dhyana Pura University Internal Grant, which is sustainable. The initial activity focused on using digital marketing to overcome the impact of the Covid19 pandemic, as a result they began to rise and achieve a very significant increase in sales, sales turnover increased by $65 \%$ from before at the beginning of the COVID-19 pandemic, which was able to sell an 
average of 100 packs. per day now 165 packs per day and continues to increase, due to a wider range of consumers (Komalasari et al, 2021).

But now the increase in sales of Nasi Koco is not so significant, it even tends to stagnate. This happens because more and more people are trying in the same field, in other words, there are many competitors. With so much competition in the Nasi Jinggo business, of course a change in product differentiation strategy is needed in dealing with and winning the competition. This is a solution offered to overcome the existing problems.

\section{Literature Review}

Nasi Koco community service project, which was started in 2020 and implemented until the time of writing, will be presented and analyzed using a Logical Framework Approach (LFA) refers to the process of analyzing a project using multiple tools, where the Logic Framework Matrix is derived as final analysis product. The matrix serves as a visual representation of project objectives, activities and anticipated outcomes, also provides a structure for defining the project components and activities and how they relate to one another and help to achieve results (Collins, 2015; Gegić, 2018). Following LFA formulation (Figure 1).

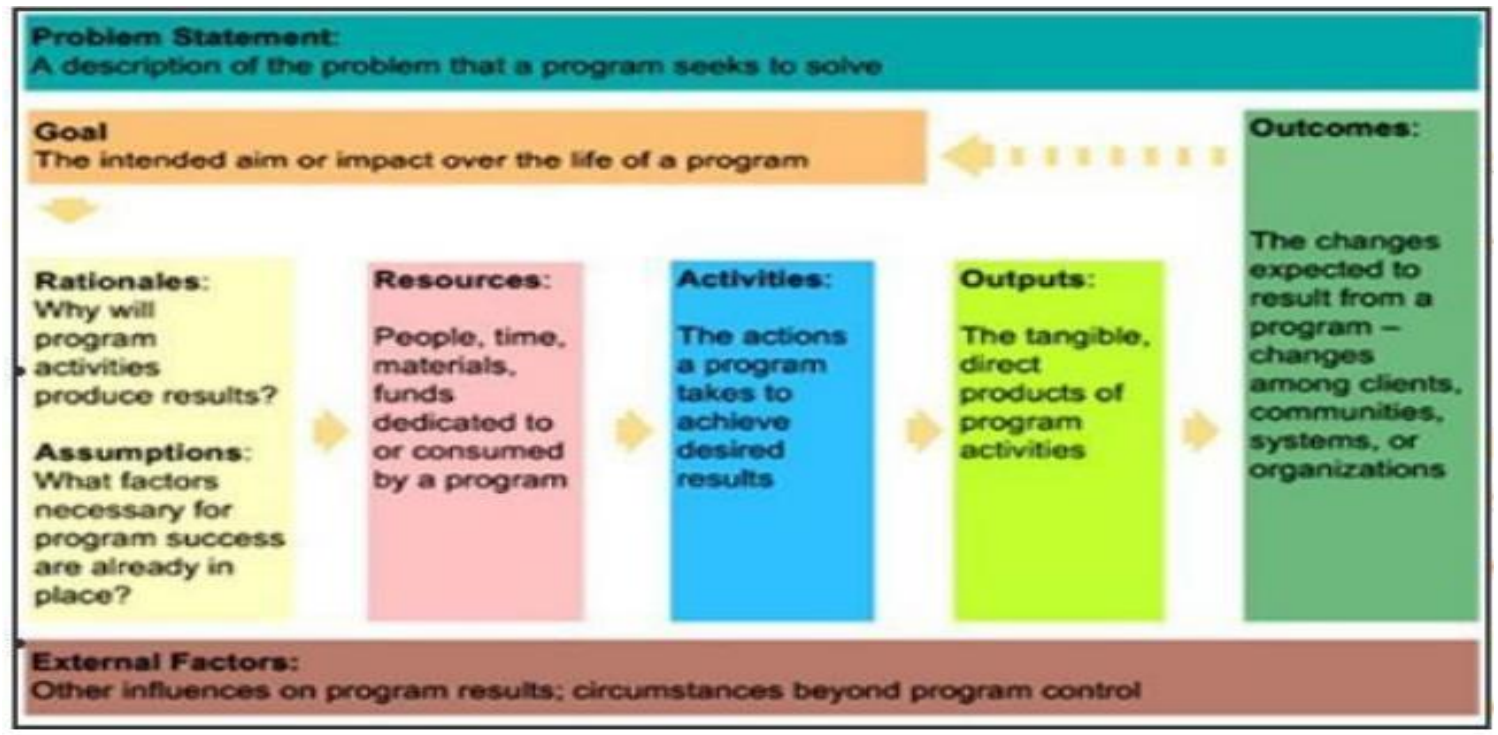

Figure 1. Logical Framework Approach (Collins, 2015)

Previously, there have been many studies reporting on women's empowerment and economic development, that the two complement each other, especially in rural areas from various backgrounds Asian countries include India, Pakistan, and Indonesia (Edyono, 2018; Erfiani et al 2020; Hassan \& Naz, 2020; Sharma \& Varma, 2016). The study states that empowering women in the patriarchal community system by prioritizing gender equality can accelerate economic development.

The women empowerment to improve economic status is through culinary entrepreneurship programs. This program was initiated because preparing food is one of the women main roles in the patriarchal community, so from this role it was later developed into a culinary entrepreneurship program.

In 2020 this community service program can be said to be successful, because the digital marketing strategy implemented was able to increase sales of Nasi Koco and overcome the problem of declining turnover as a result of the COVID-19 pandemic. In 2021 this project is still continuing by proposing a new strategy, namely a production differentiation strategy, to overcome the problem. stagnate sales due to many competitors in the same industry.

The product differentiation strategy proposed is based on local wisdom, utilizing the needs desired by the community when holding religious ceremonies. Besides being economically useful, it is also useful for preserving Balinese culture in the culinary field. 


\section{Research Method}

The study employed qualitative approaches using observation, interviews, and documentation. The result of the study base on an in-depth interview with Balinese women who understand Balinese traditional culture, the advice that can be given is to make product variations. Then it is reported by the project manager and implementer in the form of a logical framework of a qualitative descriptive approach by noting the development of women's empowerment through the realm of local wisdom and its impact on the development of the stakeholders economic status.

\section{Results and Discussion}

The author develops a matrix using a Logical Framework Approach, which describes the "Nasi Koco" women's empowerment program with a production differentiation strategy based on local wisdom-as shown in Figure 2.

Problem Statement : Production differentiation strategy needs to be done to increase the Nasi Koco sales. It is recommended that women empowerment effort use local Balinese wisdom by

\begin{tabular}{|c|c|c|c|c|}
\hline \multicolumn{4}{|c|}{$\begin{array}{l}\text { Goal : Empowering women using Balinese local wisdom can } \\
\text { improve welfare and preserve Balinese culture }\end{array}$} & \multirow[b]{2}{*}{$\begin{array}{c}\text { Outcome : } \\
\text { Empoweri } \\
\text { ng women } \\
\text { in } \\
\text { implement } \\
\text { ing } \\
\text { productio } \\
n \\
\text { differentia } \\
\text { tion } \\
\text { strategies } \\
\text { through } \\
\text { local } \\
\text { wisdom, } \\
\text { besides } \\
\text { being able } \\
\text { to increase } \\
\text { Nasi Koco } \\
\text { sales, can } \\
\text { also } \\
\text { develop } \\
\text { economic } \\
\text { status and } \\
\text { Balinese }\end{array}$} \\
\hline $\begin{array}{l}\text { Rasionales } \\
\text { : There are } \\
\text { many } \\
\text { competitor } \\
\mathrm{s} \text { in the } \\
\text { same } \\
\text { culinary } \\
\text { industry, } \\
\text { making } \\
\text { Nasi Koco } \\
\text { aware that } \\
\text { they must } \\
\text { think of } \\
\text { new } \\
\text { strategies } \\
\text { to survive } \\
\text { and win } \\
\text { the } \\
\text { competitio } \\
\mathrm{n}\end{array}$ & $\begin{array}{l}\text { Resources } \\
\text { : Bali has a } \\
\text { lot of food } \\
\text { offerings } \\
\text { needed for } \\
\text { religious } \\
\text { ceremonial } \\
\text { activities. } \\
\text { This is } \\
\text { local } \\
\text { wisdom } \\
\text { that can be } \\
\text { used for } \\
\text { production } \\
\text { differentiati } \\
\text { on } \\
\text { strategies }\end{array}$ & $\begin{array}{l}\text { Activities : } \\
\text { Organizing } \\
\text { socializatio } \\
\mathrm{n} \text { and } \\
\text { training on } \\
\text { how to } \\
\text { carry out a } \\
\text { production } \\
\text { differentiat } \\
\text { ion strategy } \\
\text { through } \\
\text { Balinese } \\
\text { local } \\
\text { wisdom }\end{array}$ & $\begin{array}{c}\text { Output : } \\
\text { Economical } \\
\text { ly value } \\
\text { products. In } \\
\text { addition to } \\
\text { Nasi Koco } \\
\text { (specially } \\
\text { wrapped } \\
\text { rice), the } \\
\text { latest is a } \\
\text { variety of } \\
\text { products } \\
\text { such as } \\
\text { Nasi } \\
\text { Tumpeng, } \\
\text { Nasi Yasa, } \\
\text { and Nasi } \\
\text { Kelangi. }\end{array}$ & \\
\hline
\end{tabular}

Figure 2. Logical Framework Matrix of the Women Empowerment Project "Nasi Koco"

\section{Rasionales}

Through an analysis of the initial situation, the team found that after carrying out community service in 2020, namely by developing the "Nasi Koco" brand logo and digital marketing strategy, it turned out that this had brought a not-so-long increase in sales. The prospect of this business makes many people join in selling the same culinary. So that many competitors appear in the same culinary industry, making Nasi Koco sales stagnant lately. Therefore, the team sees the importance of updating the strategy, namely the production differentiation strategy, using Balinese local wisdom to survive and win the competition.

In the implementation of this project, there has been a paradigm shift in utilizing Balinese local wisdom, related to the provision of food as a means of religious ceremonies. On the seller's side there are benefits of 
added economic value, while from the buyer's side it becomes very practical in preparing ceremonial facilities. Also from the community side can preserve Balinese culture.

\section{Statement of Problem and Goal}

Based on the reasons mentioned above, the team formulated the overall problem and objectives for the community development project through women's empowerment. The main problem that must be overcome is "Nasi Koco" must renew its strategy to win the competition. Bali has the potential of local wisdom in terms of culinary as a means of religious ceremonies that have not been fully realized. If this local wisdom can be used as a production differentiation strategy, women's empowerment will be able to improve their welfare

\section{Resources}

Religious ceremonies are very closely related to Balinese life and are carried out almost every day. In every religious ceremony, various culinary offerings are needed which are Balinese local wisdom. But unfortunately, because of the busyness of Balinese women today, many of whom are career women, they do not have enough time to prepare their own food offerings as a means of religious ceremonies.

This can be an opportunity that can be used by "Nasi Koco" to implement a production differentiation strategy, by selling food that will be served during religious ceremonies. There is a wide variety of ceremonial food for sale. On the other hand, this can also help the community to be practical in preparing religious ceremonies.

\section{Activities}

Activities in this project last for 2 years: 2020 and 2021. The first year has been running with a focus on digital marketing strategies (Komalasari et al, 2021) and the second year that is still ongoing is a focus on production differentiation strategies to increase sales, economic status and welfare through empowering women based on local wisdom.

In this second year, several activities were carried out. First, socializing the understanding, objectives and benefits of the production differentiation strategy on "Nasi Koco" with a scientific approach. Second, conduct socialization on women's empowerment based on local wisdom. What culinary products are needed as a means of religious ceremonies in Bali. Third, holding training on how to make and serve Nasi Tumpeng, Nasi Yasa and Nasi Kelangi in accordance with the rules of local wisdom

\section{Output}

In terms of output, this second year of community service activities made the women owners of "Nasi Koco" carry out a production differentiation strategy. In addition to the initial menu of Nasi Koco (specially wrapped rice), now they also produce Nasi Tumpeng of various sizes depending on the order, Nasi Yasa and Nasi Kelangi. This women's empowerment product is marketed online and offline to its consumers. Activities and pictures of some products can be seen in Figure 3-7.

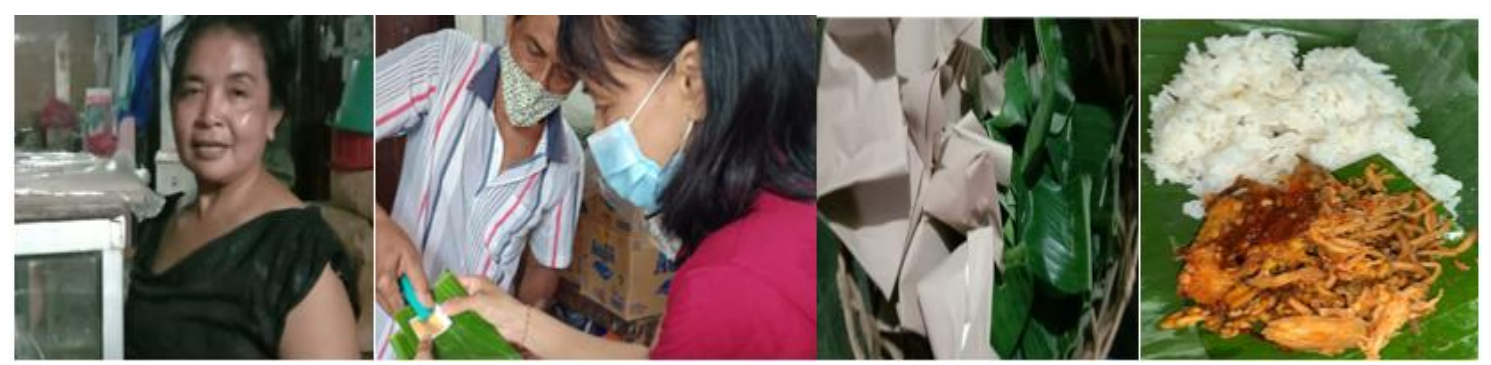

Figure 3. Ni Nyoman Puji the owner of Nasi Koco when launching the Nasi Koco logo 


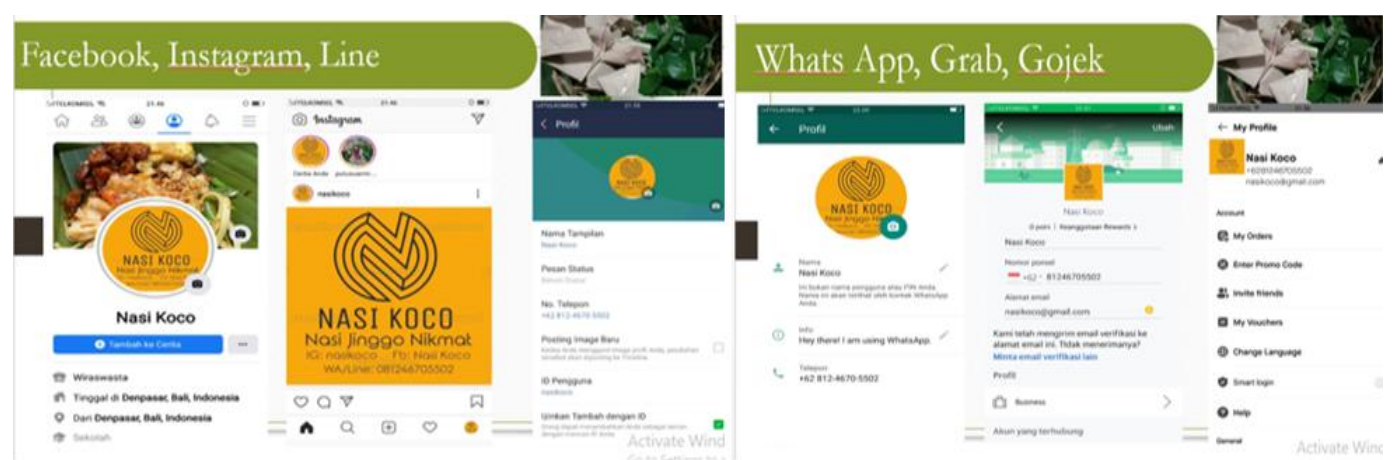

Figure 4. Nasi Koco when implementing digital marketing in the first year

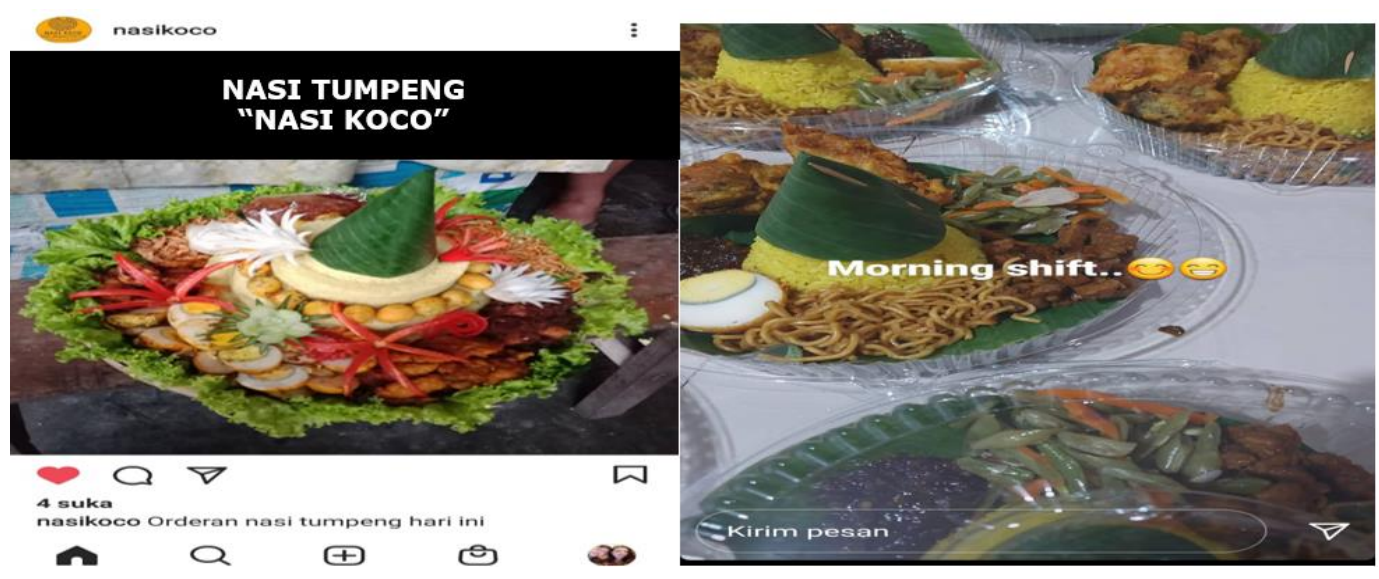

Figure 5. Implementation of the production differentiation strategy in the second year with the product name Nasi Tumpeng

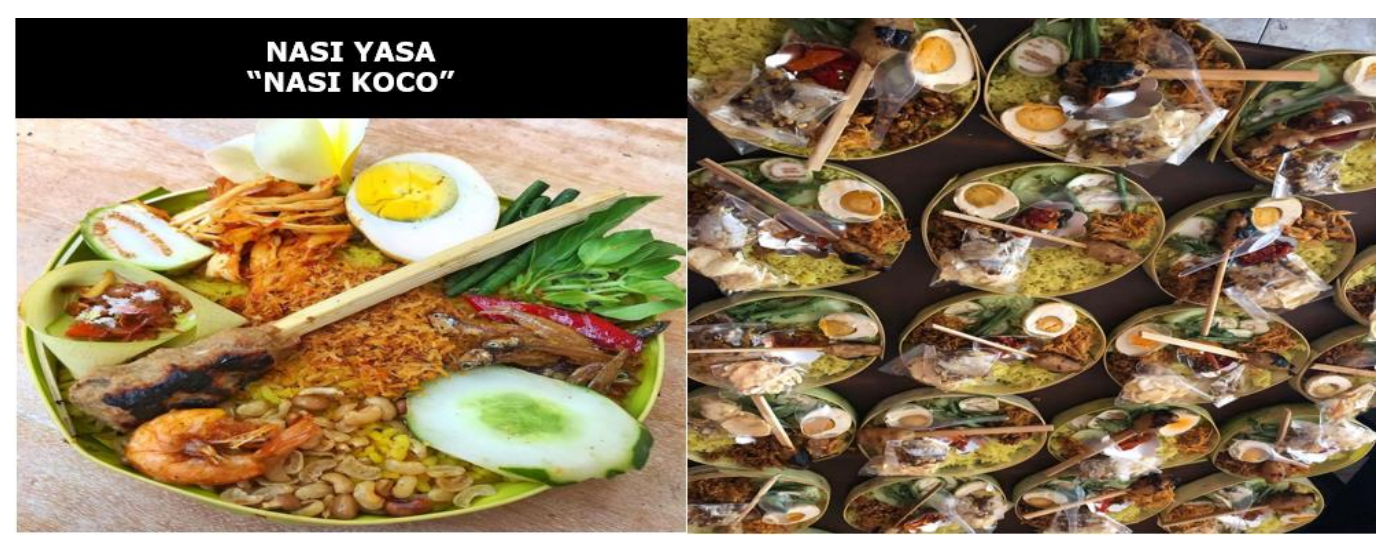

Figure 6. Implementation of the production differentiation strategy in the second year with the product name Nasi Yasa 


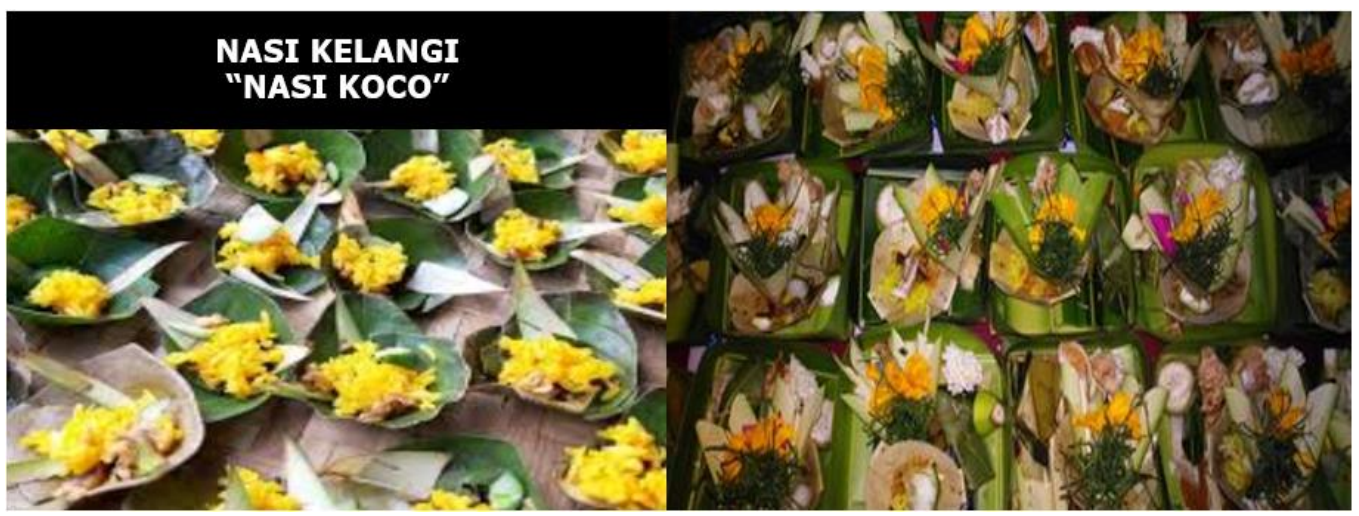

Figure 7. Implementation of the production differentiation strategy in the second year with the product name Nasi Kelangi

\section{Outcome}

From the perspective of the community service program team, this project has been able to have an observable impact on society. In terms of social impact, women's empowerment projects are felt by Nasi Koco and the surrounding community as a whole. For Nasi Koco, there was a good increase in sales. For the local community, with the variety of products from Nasi Koco, it gives consumers many choices, and most importantly it really helps them to prepare for religious ceremonies that are part of the Balinese people daily life. Now many culinary industries are starting to look at the variety of products that Nasi Koco has. However, this must always be addressed properly so that it can be overcome with creativity and innovation in the future. If there are competitors, Nasi Koco must be able to have its own unique product that attracts loyal consumers to the products issued by Nasi Koco.

\section{Conclusion and Implications}

The women's empowerment program at Nasi Koco has been able to produce not only a wide variety of marketed products, and gain economic benefits from it, but has also triggered the culinary industry in the same field to be interested in following the steps taken by Nasi Koco in implementing a production differentiation strategy. In the future, it is hoped that they will be able to compete wisely to enhance each other's innovation and creativity in order to achieve the welfare of society as a whole.

The theoretical contribution of this community service is that the product differentiation strategy that has been studied in theory can be directly applied to Nasi Koco SMEs and has real impacts and benefits. The managerial implication is that Nasi Koco SMEs must be able to adapt to all changes and continue to develop themselves if they want to exist and win the competition in the culinary industry. The next suggestion for community service is pay attention to improving the taste, sanitation and hygiene of Nasi Koco production.

\section{References}

Al Maraghi, M., \& Mardian, I. (2020). Pengaruh Diferensiasi Dan Inovasi Produk Terhadap Loyalitas Pelanggan Pada Mamachi Kota Bima. Bisman-Jurnal Bisnis \& Manajemen, 5(01), 54-64.

Alfatihah, A., (2020). Pengaruh Strategi Diferensiasi Produk Terhadap Keputusan Pembelian Kuliner Ayam O’Chiken Pekanbaru Ditinjau Menurut Ekonomi Syariah (Doctoral dissertation, Universitas Islam Negeri Sultan Syarif Kasim Riau).

Chen, J., Wang, X., \& Chu, Z. (2020). Capacity sharing, product differentiation and welfare. Economic research-Ekonomska istraživanja, 33(1), 107-123.

Collins, K. B. (2015, March 23). What is a Log Frame? American University Online. https://programs.online.american.edu/online-graduatecertificates/projectmonitoring/resources/what-is-a-logframe

Eddyono, S. W. (2018). Women's Empowerment in Indonesia: A Poor Community in Jakarta. Routledge. Erfiani, N.M.D, Susanto, P.C, Darmawijaya, IP, and Lestari, P.I.(2020). Empowering Women And Fostering Green Entrepreneurship Trough Herbal Product Development In Catur Kintamani. Proceeding of The 4th International Conference on Family Business and Entrepreneurship. http://ejournal.president.ac.id/presunivojs/index.php/ICFBE/article/view/1377 
Gegić, M. M. (2018). Logical framework matrix and project proposal quality. Tehnika, 73(6), 889-896.

Hassan, M. ul, \& Naz, A. (2020). Education for Women Entrepreneurial Attitudes and Intentions: The Role of Perceptions on Gender Equality and Empowerment. Pakistan Journal of Commerce and Social Sciences, 14(1), 63-98.

He, D., \& Deng, X. (2020). Price competition and product differentiation based on the subjective and social effect of consumers' environmental awareness. International journal of environmental research and public health, 17(3), 716.

Komalasari, Y., Suryantari, E. P., \& Krismawintari, N. P. D. (2021). Pemanfaatan Media Daring sebagai Upaya Peningkatan Penjualan Nasi Koco di Banjar Gerenceng Desa Pemecutan Kaja Denpasar Utara Bali. Paradharma (Jurnal Aplikasi IPTEK), 5(1).

Kustiandi, J., Jaelani, M.I., Khumairoh, N., Pakpahan, N., Azizah, R.N. and Hafidzoh, S.A., (2020). Peningkatan Kesejahteraan Masyarakat Melalui Pelatihan Diferensiasi Produk Olahan Susu Sapi Desa Ngembal. Jurnal Graha Pengabdian, 2(3), pp.242-249.

Norfiyanti, K. (2020). Analisis Diferensiasi Produk dan Persepsi Harga Donat Madu Cihanjuang (Studi Kasus Pada Konsumen Outlet Godean, Yogyakarta). UPAJIWA DEWANTARA: Jurnal Ekonomi, Bisnis dan Manajemen Daulat Rakyat, 4(2), 85-94.

Putro, S.B., Teguh, M. and Harunurrasyid, H., (2020). Strategi Diferensiasi dan Diversifikasi Produk Dan Pengaruhnya Terhadap Penjualan Pada Industri Souvenir Songket Di Kota Palembang (Doctoral dissertation, Sriwijaya University).

Sharma, P., \& Varma, S. (2016). Women Empowerment through Entrepreneurial Activities of Self Help Groups. Indian Research Journal of Extension Education, 8(1), 46-51.

Sheng, T. W. (2020). Product Differentiation, Customer Equity, and Purchase Intention: An Empirical Study of Original Content on Video Streaming Service.

Wibawanto, S. and Pratama, M.P., (2020). Diferensiasi Produk, Pengembangan Desain Kemasan, dan Pemasaran Online Bagi Kelompok Pengrajin Songkok Desa Bandung Kabupaten Kebumen. JCSE: Journal of Community Service and Empowerment, 1(1), pp.8-12. 